\title{
Larval and early juvenile development of Paralomis granulosa reared at different temperatures: tolerance of cold and food limitation in a lithodid crab from high latitudes
}

\author{
K. Anger ${ }^{1, *}$, S. Thatje ${ }^{2}$, G. Lovrich ${ }^{3}$, J. Calcagno ${ }^{4}$ \\ ${ }^{1}$ Biologische Anstalt Helgoland, Stiftung Alfred-Wegener-Institut für Polar- und Meeresforschung, 27498 Helgoland, Germany \\ ${ }^{2}$ Alfred-Wegener-Institut für Polar- und Meeresforschung, 27568 Bremerhaven, Germany \\ ${ }^{3}$ Centro Austral de Investigaciones Científicas (CADIC), 9410 Ushuaia, Argentina \\ ${ }^{4}$ Facultad de Ciencias Exactas y Naturales, Universidad de Buenos Aires, Buenos Aires, Argentina
}

\begin{abstract}
Paralomis granulosa Jacquinot is a commercially fished lithodid crab species living in subantarctic and cold-temperate regions of southern South America. Its larval stages (Zoea I, II, Megalopa) are fully lecithotrophic, developing in the complete absence of food from hatching through metamorphosis; first feeding occurs in the first juvenile crab stage. In laboratory rearing experiments conducted at constant $1,3,6,9,12$, and $15^{\circ} \mathrm{C}$, we studied rates of larval and early juvenile survival and development in relation to temperature. At $1{ }^{\circ} \mathrm{C}$, many larvae $(52 \%)$ reached the Megalopa stage almost 2 mo after hatching, but all died subsequently without passing through metamorphosis. Larval development was successfully completed at all other temperatures, with maximum survival at 6 to $9^{\circ} \mathrm{C}$. The time of non-feeding larval development from hatching to metamorphosis lasted, on average, from $24 \mathrm{~d}\left(\right.$ at $\left.15^{\circ} \mathrm{C}\right)$ to almost 4 mo $\left(117 \mathrm{~d}\right.$, at $\left.3^{\circ} \mathrm{C}\right)$. When the experiment was terminated $1 \mathrm{yr}$ after hatching, the $3 \mathrm{rd}\left(3^{\circ} \mathrm{C}\right)$ to 8 th $\left(15^{\circ} \mathrm{C}\right)$ juvenile crab instar had been reached. The relationship between the time of development through individual larval or juvenile stages $(y)$ and temperature $(T)$ was described as a power function $\left(y=\mathrm{a} \times T^{\mathrm{b}}\right.$, or $\log [y]=\log [\mathrm{a}]+\mathrm{b} \cdot \log [\mathrm{T}]$; the same regression model was also used to describe the temperature-dependence of cumulative periods of development from hatching. The wide thermal tolerance window for successful larval development (at least 3 to $15^{\circ} \mathrm{C}$ ) and the broad geographic range of this species show that the early life-cycle stages of $P$. granulosa are cold-eurythermal. This physiological trait together with larval independence of food indicate that this lithodid crab species is well adapted to severe conditions of cold in combination with the food-limitation in subantarctic regions. Since similar traits have been also observed in other Lithodidae, we suggest that early life-history adaptations to low temperatures and low planktonic productivity may explain the high number of lithodid species occurring at high latitudes and in the deep sea, i.e. in conditions under which other Decapoda show strongly reduced diversity.
\end{abstract}

KEY WORDS: Lithodidae $\cdot$ Paralomis granulosa $\cdot$ Temperature $\cdot$ Larval development $\cdot$ Juvenile growth $\cdot$ Cold tolerance

\section{INTRODUCTION}

A macroecological pattern in the geographical distribution of higher animal and plant taxa is a decreasing trend in species diversity from low latitudes towards the poles (for recent review of the literature, examples, and discussion of relevant theories see Chown et al.
2000). Among the marine benthic invertebrates, this pattern has been particularly well documented for molluscs and crustaceans (e.g. Knox 1994, Clarke 1997, Crame \& Clarke 1997). In a recent review of the distribution and life histories of temperate and antiboreal Decapoda of the SW Atlantic Ocean, Spivak (1997) listed a total of 243 species reported from the South 
American coasts from 25 to $55^{\circ} \mathrm{S}$. Among these, only 37 species $(15 \%)$ have been found in the southernmost region including Tierra del Fuego, the Falkland Islands (Islas Malvinas) and South Georgia (ca. 50 to $55^{\circ} \mathrm{S}$ ). In another biogeographical review for the entire antiboreal region south of $\sim 42^{\circ} \mathrm{S}$ (including the southern parts of the Atlantic, Pacific and Indian Oceans) Gorny (1999) listed 132 decapod crustacean species, with only $12(9 \%)$ of these occurring south of the Antarctic Convergence. The impoverishment of the Antarctic decapod fauna during periods of climate cooling, about 20 million yr ago, is well documented in the fossil record also (Clarke 1993, Crame 1999, Stilwell \& Feldmann 2000), indicating that declining temperatures and/or associated factors such as low productivity were critical factors in this process.

Besides food limitation in high-latitude environments (Knox 1994), physiological constraints to evolutionary cold adaptation are considered a principal cause of these patterns in biodiversity (Pörtner et al. 2000). In ectothermic animals in particular, their energetic metabolism appears to be affected by both unfavourably high and unfavourably low temperatures. When temperature drops below a species-specific critical level, insufficient aerobic capacity of the mitochondria leads to a shift towards an anaerobic mode of metabolism and, as a consequence, to an insufficient supply of cellular energy (for review of physiological mechanisms see Pörtner 2001, 2002). In most marine decapod taxa, this problem appears to be aggrevated by synergistic effects of $\mathrm{Mg}^{2+}$ ions, which reduce the scope for activity, especially at low temperatures (Frederich et al. 2000, 2001). Since the Decapoda and other marine invertebrates in high latitudes originated from warm-water ancestors (Arntz et al. 1994), the physiological problems typically faced under cold conditions require special evolutionary adaptations (Pörtner 2002), implying that relatively few, particularly adaptable, species may be successful.

Within the complex life cycles of decapod crustaceans and other marine invertebrates, the early (larval and juvenile) stages represent a physiological bottleneck, as they are generally more vulnerable to thermal, nutritional and other stress than the conspecific adults (for review see Anger 2001). In high latitudes, a mismatch of low water temperatures (causing long development times) and a short season of plankton production (implying lack of food throughout most of their pelagic development) should select against planktonic larvae. This may explain another macroecological pattern, namely a decreasing tendency in the number of species with planktonic larvae in latitudinal clines from warm to cold regions, i.e. 'Thorson's rule' (Thorson 1950; for recent discussion see Gallardo \& Penchaszadeh 2001). While many species in high lati- tudes have evolved an abbreviated, often non-feeding mode of larval development (Gore 1985, Rabalais \& Gore 1985, Anger 2001), others have completely supressed their planktonic larval phase. However, phylogenetic constraints may, in some taxa, prevent the evolution of an abbreviated or direct mode of development, so that the particular vulnerability of larvae may have contributed to the latitudinal gradients in biodiversity.

Despite severe problems associated with cold- and food-limited conditions in high latitudes, however, several decapod taxa have successfully adapted to Arctic or Antarctic biota (Christiansen \& Christiansen 1962, Arntz \& Gorny 1991, Arntz et al. 1997, 1999, Gorny 1999, Paul et al. 2002). In addition to some caridean shrimps and pagurid hermit crabs, this is most conspicuous in the distribution of stone crabs or king crabs (Lithodidae; for recent review see Zaklan 2002). In Spivak's (1997) species list, only 9 (3.7\%) out of 243 decapod species recorded for the SW Atlantic region belong to this family, but 7 of these 9 (i.e. $78 \%$ ) occur in the southernmost parts of this area, where they contribute about $19 \%$ to the regional decapod fauna. Similarly, 18 of $80 \mathrm{crab}$ species recorded for the cold-temperate and subarctic waters of Alaska (22\%) are lithodids (Stevens 2002), while warm-temperate and tropical decapod faunas show typically much lower proportions of stone crabs (for references see Dawson 1989). Moreover, recent observations have shown that lithodid crabs occur also in the extremely cold coastal waters of Greenland (Woll \& Burmeister 2002) and in the high Antarctic Sea (Klages et al. 1995, Arana \& Retamal 1999). It is thus not surprising that lithodids belong also to the most typical inhabitants of another cold- and food-limited environment, the deep sea (Chevaldonné \& Olu 1996, Rex \& Etter 1997, Gorny 1999, Zaklan 2002).

Since, as far as is known, the Lithodidae have several larval stages (McLaughlin et al. 2001, in press, and earlier papers cited therein), special adaptations to the conditions prevailing in high latitudes or in the deep sea are also required in their early life-history stages. Compared with other Anomura (including the closely related pagurid hermit crabs), lithodid crabs show tendencies towards an abbreviation of the pelagic larval phase and lecithotrophy, i.e. towards a foodindependent mode of larval development (Anger 1996, Shirley \& Zhou 1997, Lovrich et al. 2003). This holds true also for the subject of the present study, the subantarctic stone crab Paralomis granulosa Jacquinot. Recent observations on its larval development (comprising only 2 zoeal stages and a megalopa: Campodonico \& Guzman 1981, McLaughlin et al. in press), larval survival and biochemical composition in laboratory cultures with and without food have shown that its 
development from hatching to metamorphosis is fully endotrophic, being mainly based on a degradation of internal lipid reserves remaining from the egg yolk (Calcagno et al. in press, Kattner et al. in press).

Complete larval independence of external food sources may be considered a reproductive adaptation of Paralomis granulosa to conditions of low or seasonally brief productivity in subantarctic regions. In addition, in this species we would also expect larval adaptations to low temperatures. Since the zoeae hatch during the austral winter (Lovrich \& Vinuesa 1999), they should be cold-tolerant, and their endotrophic potential should suffice for extended periods (weeks to months) of non-feeding development in the plankton. However, very little is known about the effects of temperature on the early life-history stages of this species. In a previous experimental study (Vinuesa et al. 1989), most larvae died in the zoeal stages, and metamorphosis from the megalopa to the first juvenile stage was not reached in any of the conditions tested $\left(5\right.$ to $\left.14^{\circ} \mathrm{C}\right)$.

In the present investigation on Paralomis granulosa, we studied the influence of temperature on survival and development of larvae and early juveniles, attempting to identify early life-history adaptations in this subantarctic species. Possible adaptive traits should also enhance our understanding of macroecological patterns such as latitudinal gradients in biodiversity, Thorson's rule, and the exceptional role of the Lithodidae within these patterns.

\section{MATERIALS AND METHODS}

The capture and maintenance of Paralomis granulosa as well as the rearing of their larvae are described in detail by Lovrich et al. (2003) and Calcagno et al. (in press). Briefly, ovigerous females were collected in April 2001 from the Beagle Channel (Tierra del Fuego, southern Argentina) using commercial fishing boats (for details of local crab fisheries see Lovrich 1997). They were kept in flow-through seawater aquaria at the local research institute (Centro Austral de Investigaciones Cientificas), and eventually transported with the German research icebreaker 'Polarstern' to the marine biological laboratory on Helgoland (Biologische Anstalt Helgoland), Germany. Subsequently, the crabs were maintained in flow-through seawater aquaria at a constant $6^{\circ} \mathrm{C}$, ca. $32 \%$, and a $12: 12 \mathrm{~h}$ light:dark cycle.

Freshly hatched, actively swimming larvae from 3 different females (A, B, C) were randomly selected and subsequently reared in individual $100 \mathrm{ml}$ bowls kept under the same conditions of salinity and light. Since Paralomis granulosa releases only low numbers of larvae per night (normally <100, similar to the number reported for another lithodid species, Lithodes maja; see Anger 1996), we had to start 'parallel' experiments with different rearing temperatures using sibling larvae that hatched on different days. As rearing temperatures, we used $1,3,6,9,12$ and $15^{\circ} \mathrm{C}$; the lowest and the highest temperature, however, were tested only with larvae from 1 hatch (A). The initial number of larvae per treatment and hatch was $\mathrm{n}=48$, except for the experiment with Hatch B larvae reared at $9^{\circ} \mathrm{C}$, where insufficient material allowed an initial number of only 46.

The larvae were reared without addition of food, since previous experiments (McLaughlin et al. 2001, in press, Calcagno et al. in press, Kattner et al. in press) had shown that all larval stages of Paralomis granulata are non-feeding. From the day of metamorphosis onwards, juvenile crabs were fed with Artemia sp. nauplii. At 9 to $15^{\circ} \mathrm{C}$ the culture water (and for juveniles also the food) was changed every other day; at lower temperatures the changes were made every third day. In all treatments, the larvae or juveniles were checked daily for moults or mortality.

The rearing experiments with 1 hatch (A) were continued throughout 1 yr, from August 2001 to August 2002, while all other experiments were terminated as soon as Crab Stage II was reached. Because of accidental loss of data, the experiment with Hatch A larvae reared at $12^{\circ} \mathrm{C}$ was prematurely terminated at Crab Stage III (instar stage), so no data were obtained for later juvenile stages in this group.

Our statistical analyses followed Sokal \& Rohlf (1995). A 1-way ANOVA followed by comparisons between pairs of means was used for comparing survival and time of development at each larval stage. The durations of individual (larval or juvenile) stages as well as cumulative periods of development (e.g. from hatching to metamorphosis) are described as power functions of temperature (i.e. as linear regressions after log-transformation of both variables). Arithmetic mean values for different females rather than individual data were used as replicate values in the regression analyses. Slope parameters of the linearized regressions were compared with a test for heterogeneity of slopes using $F$ statistics. Where average values with error estimates are given in the text or in figures and tables, these represent arithmetic mean values $\pm 1 \mathrm{SD}$.

\section{RESULTS}

\section{Rates of survival}

The survival of Paralomis granulosa through successive larval and juvenile stages varied greatly among temperatures and, at identical temperatures, among 
hatches from different females (Table 1). Since the experiments with Hatches B and $\mathrm{C}$ were conducted only at 3 to $12^{\circ} \mathrm{C}$ and, moreover, terminated at Crab Stage II, the survival rates of different hatches can be compared only in this temperature range and only in the larval stages and in the first juvenile instar. For all larval stages, Hatch $\mathrm{C}$ showed lower survival than the other 2 hatches, except at $12^{\circ} \mathrm{C}$. In contrast, Hatch $\mathrm{A}$ showed high survival of all larval stages, but high mortality at the first crab stage at $12^{\circ} \mathrm{C}$ and not at the other temperatures.

While the comparison among different hatches did not reveal a clear pattern, temperature was shown to have strong effects on survival. At the lowest temperature $\left(1^{\circ} \mathrm{C}\right.$, tested only for Hatch A), $52 \%$ of the larvae survived through the 2 zoeal stages, but none of the survivors reached metamorphosis; i.e. complete mortality occurred at the Megalopa stage. The next higher temperature $\left(3^{\circ} \mathrm{C}\right)$ allowed for 10 to $31 \%$ survival from hatching through metamorphosis in all hatches; however, complete mortality subsequently occurred at the first or second juvenile stage (Table 1). The highest level of survival was observed at $6^{\circ} \mathrm{C}$, with a decreasing tendency at higher temperatures (accidental loss of data precluded inclusion of $12^{\circ} \mathrm{C}$ ). When the experiments were terminated $1 \mathrm{yr}$ after hatching, the survivors had maximally reached Juvenile Instars II $\left(3^{\circ} \mathrm{C}\right)$, VI $\left(6^{\circ} \mathrm{C}\right)$, VII $\left(9^{\circ} \mathrm{C}\right)$, and VIII $\left(15^{\circ} \mathrm{C}\right)$. Tables 1 to 3 show survival and development data for the latest juvenile instars near the end of the experiments only when all surviving individuals at a given temperature had reached these stages in August 2002. For instance, at $15^{\circ} \mathrm{C}$, some crabs were at that time already in Juvenile
Stage VIII, while others were still at Stage VI; in this case, the data for Stages VII and VIII were incomplete and thus not included in our tables or statistical analyses.

\section{Rates of development}

The development times of individual larval and juvenile stages are given in Table 2, the cumulative development times from hatching in Table 3. Among larvae originating from different females, statistically significant differences in individual stage durations were observed only in the 2 zoeal stages reared at 3 and $12^{\circ} \mathrm{C}$. Variability among hatches often showed opposite tendencies in successive stages; e.g. Zoea I duration was shorter in Hatch A than in Hatch B, but Zoea II was longer in Hatch A than in Hatch B; Table 2 ). As a corollary, the cumulative durations to successive stages at identical temperatures were generally similar among the 3 hatches (no statistically significant differences: Table 3).

Increasing temperature had a clearly accelerating effect on development, especially in the lower temperature range. While an increase from 1 to $3^{\circ} \mathrm{C}$ or from 3 to $6^{\circ} \mathrm{C}$ caused a substantial decrease in moult-cycle duration in all stages, the differences observed between 12 and $15^{\circ} \mathrm{C}$ were mostly insignificant, the only exception being the Megalopa (Table 2). Within the temperature range tested in this study $\left(1\right.$ to $\left.15^{\circ} \mathrm{C}\right)$, the Zoea I lasted on average 3 to $17 \mathrm{~d}$ and Zoea II 4 to $39 \mathrm{~d}$. The Megalopa stage (data available only for 3 to $15^{\circ} \mathrm{C}$ ) lasted 17 to $84 \mathrm{~d}$. Complete larval development from hatching to

Table 1. Paralomis granulosa. Rates of survival of individual developmental stages (\% of survivors to a given stage) and cumulative survival from hatching to a given stage (as \% of initial number at hatching [cum. \%]). $\mathrm{n}=46$ for Female $\mathrm{B}$ at $9^{\circ} \mathrm{C}$, $\mathrm{n}=48 \mathrm{for}$ all other experiments. Italics and bold-face: cumulative survival

\begin{tabular}{|c|c|c|c|c|c|c|c|c|c|c|c|c|c|c|c|c|c|c|}
\hline \multirow{2}{*}{$\begin{array}{l}\mathrm{T} \\
\left({ }^{\circ} \mathrm{C}\right) \\
1\end{array}$} & \multirow{2}{*}{$\begin{array}{c}\text { Female } \\
\text { A }\end{array}$} & \multirow{2}{*}{$\begin{array}{c}\begin{array}{c}\text { Zoea I } \\
\%\end{array} \\
90\end{array}$} & \multicolumn{2}{|c|}{$\begin{array}{l}\text { Zoea II } \\
\% \quad \text { cum.\% }\end{array}$} & \multicolumn{2}{|c|}{$\begin{array}{l}\text { Megalopa } \\
\% \text { cum. \% }\end{array}$} & \multicolumn{2}{|c|}{$\begin{array}{c}\text { Crab I } \\
\% \quad \text { cum. \% }\end{array}$} & \multicolumn{2}{|c|}{$\begin{array}{l}\text { Crab II } \\
\% \quad \text { cum. \% }\end{array}$} & \multicolumn{2}{|c|}{$\begin{array}{l}\text { Crab III } \\
\% \text { cum. \% }\end{array}$} & \multicolumn{2}{|c|}{$\begin{array}{l}\text { Crab IV } \\
\% \quad \text { cum.\% }\end{array}$} & \multicolumn{2}{|c|}{$\begin{array}{l}\text { Crab V } \\
\% \text { cum. } \%\end{array}$} & \multicolumn{2}{|c|}{$\begin{array}{l}\text { Crab VI } \\
\% \text { cum. \% }\end{array}$} \\
\hline & & & 58 & 52 & 0 & 0 & & & & & & & & & & & & \\
\hline \multirow[t]{3}{*}{3} & A & 94 & 71 & 67 & 47 & 31 & 20 & 6 & & & & & & & & & & \\
\hline & B & 92 & 66 & 60 & 38 & 23 & 0 & 0 & & & & & & & & & & \\
\hline & $\mathrm{C}$ & 79 & 76 & 44 & 17 & 10 & 0 & 0 & & & & & & & & & & \\
\hline \multirow[t]{3}{*}{6} & A & 98 & 89 & 88 & 95 & 83 & 90 & 75 & 100 & 75 & 94 & 71 & 100 & 71 & & & & \\
\hline & B & 90 & 86 & 77 & 89 & 69 & 79 & 54 & & & & & & & & & & \\
\hline & $\mathrm{C}$ & 96 & 70 & 63 & 59 & 38 & 58 & 23 & & & & & & & & & & \\
\hline \multirow[t]{3}{*}{9} & A & 98 & 85 & 83 & 85 & 71 & 85 & 58 & 90 & 54 & 92 & 50 & 83 & 42 & 60 & 25 & 75 & 19 \\
\hline & B & 98 & 78 & 72 & 71 & 54 & 100 & 54 & & & & & & & & & & \\
\hline & $\mathrm{C}$ & 100 & 90 & 90 & 81 & 73 & 89 & 54 & & & & & & & & & & \\
\hline \multirow[t]{3}{*}{12} & A & 98 & 94 & 83 & 86 & 58 & 53 & 4 & 10 & & & & & & & & & \\
\hline & B & 96 & 84 & 77 & 54 & 42 & 70 & 29 & & & & & & & & & & \\
\hline & C & 96 & 61 & 58 & 46 & 27 & 92 & 25 & & & & & & & & & & \\
\hline 15 & A & 98 & 94 & 83 & 82 & 73 & 50 & 38 & 67 & 25 & 92 & 23 & 91 & 21 & 70 & 15 & 57 & 8 \\
\hline
\end{tabular}


Table 2. Paralomis granulosa. Duration of development (d) of successive larval and juvenile stages from 3 different females $(\mathrm{A}, \mathrm{B}, \mathrm{C})$ at different temperatures

\begin{tabular}{|c|c|c|c|c|c|c|c|c|c|c|c|c|c|c|c|}
\hline \multirow{2}{*}{$\begin{array}{l}\mathrm{T} \\
\left({ }^{\circ} \mathrm{C}\right)\end{array}$} & \multirow{2}{*}{ Female } & \multicolumn{2}{|c|}{ le Zoea I } & \multicolumn{2}{|c|}{ Zoea II } & \multicolumn{2}{|c|}{ Megalopa } & \multicolumn{2}{|c|}{ Crab I } & \multicolumn{2}{|c|}{ Crab II } & Crab III & Crab IV & Crab V & Crab VI \\
\hline & & $x$ & $\pm \mathrm{SD}$ & $x$ & $\pm \mathrm{SD}$ & $x$ & $\pm \mathrm{SD}$ & $x$ & $\pm \mathrm{SD}$ & & $\pm \mathrm{SD}$ & $x \quad \pm$ SD & $x \quad \pm \mathrm{SD}$ & $x \quad \pm$ SD & $x \quad \pm \mathrm{SD}$ \\
\hline 1 & $\mathrm{~A}$ & 16.9 & (1.1) & 39.2 & $(2.7)$ & & & & & & & & & & \\
\hline \multirow[t]{3}{*}{3} & $\mathrm{~A}$ & 7.8 & $(1.7)$ & 26.9 & $(2.8)$ & 83.7 & $(2.4)$ & \multicolumn{2}{|c|}{$102.3(11.0)$} & & & & & & \\
\hline & B & 9.7 & $(1.5)$ & 25.5 & $(1.6)$ & 82.0 & $(3.2)$ & & & & & & & & \\
\hline & $\mathrm{C}$ & 9.6 & (1.3) & 21.6 & (1.8) & 85.8 & (1.9) & & & & & & & & \\
\hline \multirow[t]{3}{*}{6} & $\mathrm{~A}$ & 5.2 & $(0.5)$ & 10.9 & $(0.5)$ & 39.2 & $(2.2)$ & 48.4 & $(3.0)$ & \multirow[t]{3}{*}{55.8} & \multirow[t]{3}{*}{$(6.4)$} & \multirow[t]{3}{*}{$75.5(15.6)$} & \multirow[t]{3}{*}{$88.4(15.4)$} & & \\
\hline & B & 5.3 & $(0.5)$ & 10.9 & $(0.5)$ & 37.8 & $(1.9)$ & 47.4 & $(3.5)$ & & & & & & \\
\hline & $\mathrm{C}$ & 5.6 & (1.3) & 10.3 & $(1.0)$ & 38.8 & $(1.8)$ & 45.6 & $(4.0)$ & & & & & & \\
\hline \multirow[t]{3}{*}{9} & A & 3.4 & $(0.5)$ & 6.3 & $(0.6)$ & 31.6 & $(2.3)$ & 33.8 & $(2.6)$ & \multirow[t]{3}{*}{37.0} & \multirow[t]{3}{*}{$(3.2)$} & $(6.2)$ & \multirow[t]{6}{*}{53.3} & \multirow[t]{6}{*}{74.8 (12.5) } & 74.4 (17.7) \\
\hline & B & 3.5 & $(0.5)$ & 5.8 & $(0.6)$ & 28.6 & $(2.8)$ & 35.1 & $(2.5)$ & & & \multirow{5}{*}{50.6} & & & \\
\hline & $\mathrm{C}$ & 3.4 & $(0.5)$ & 6.2 & $(0.4)$ & 32.0 & $(2.7)$ & 33.4 & $(1.9)$ & & & & & & \\
\hline \multirow[t]{3}{*}{12} & $\mathrm{~A}$ & 3.0 & $(0.0)$ & 4.9 & $(0.3)$ & 23.0 & $(2.5)$ & 24.1 & $(8.8)$ & \multirow{3}{*}{\multicolumn{2}{|c|}{$29.5(0.7)$}} & & & & \\
\hline & B & 4.0 & $(0.0)$ & 3.5 & $(0.5)$ & 22.2 & $(1.8)$ & 28.0 & $(2.9)$ & & & & & & \\
\hline & $\mathrm{C}$ & 4.0 & $(0.0)$ & 3.5 & $(0.5)$ & 24.1 & $(1.4)$ & 27.4 & (1.7) & & & & & & \\
\hline 15 & A & 3.0 & $(0.0)$ & 4.1 & $(0.5)$ & 17.4 & $(1.6)$ & 26.4 & $(2.7)$ & 28.4 & $(4.8)$ & $32.9 \quad(5.2)$ & 39.9 (8.9) & $43.7 \quad(4.3)$ & $53.0(12.8)$ \\
\hline
\end{tabular}

Table 3. Paralomis granulosa. Cumulative time of development (days from hatching) to successive larval and juvenile stages from 3 different females $(\mathrm{A}, \mathrm{B}, \mathrm{C})$ at different temperatures

\begin{tabular}{|c|c|c|c|c|c|c|c|c|c|c|c|c|c|c|}
\hline \multirow{2}{*}{$\begin{array}{l}\mathrm{T} \\
\left({ }^{\circ} \mathrm{C}\right)\end{array}$} & \multirow{2}{*}{ Female } & \multirow{2}{*}{\multicolumn{2}{|c|}{$\begin{array}{c}\text { Megalopa } \\
x \quad \pm \text { SD }\end{array}$}} & \multicolumn{2}{|c|}{ Crab I } & \multicolumn{2}{|c|}{ Crab II } & \multirow{2}{*}{$\begin{array}{l}\text { Crab III } \\
x \quad \pm \text { SD }\end{array}$} & \multicolumn{2}{|c|}{ Crab IV } & \multicolumn{2}{|c|}{ Crab V } & Crab VI & Crab VII \\
\hline & & & & $x$ & $\pm \mathrm{SD}$ & $x$ & $\pm \mathrm{SD}$ & & $x$ & $\pm \mathrm{SD}$ & $x$ & $\pm \mathrm{SD}$ & $x \quad \pm \mathrm{SD}$ & $x \quad \pm$ SD \\
\hline 1 & $\mathrm{~A}$ & 56.3 & $(2.8)$ & & & & & & & & & & & \\
\hline \multirow[t]{3}{*}{3} & $\mathrm{~A}$ & 34.6 & $(3.2)$ & 117.4 & $(2.7)$ & 219.0 & $(9.5)$ & & & & & & & \\
\hline & B & 34.8 & $(1.3)$ & 115.9 & (3.8) & & & & & & & & & \\
\hline & $\mathrm{C}$ & 30.5 & $(1.5)$ & 115.4 & $(2.0)$ & & & & & & & & & \\
\hline \multirow[t]{3}{*}{6} & $\mathrm{~A}$ & 16.0 & $(0.4)$ & 55.2 & $(2.4)$ & 103.7 & $(4.6)$ & $154.4(8.4)$ & 218.5 & (19.1) & 266.3 & (11.6) & & \\
\hline & B & 16.2 & $(0.7)$ & 54.0 & $(2.0)$ & 101.5 & $(4.5)$ & & & & & & & \\
\hline & $\mathrm{C}$ & 15.8 & $(0.7)$ & 48.9 & $(2.0)$ & 99.6 & (3.7) & & & & & & & \\
\hline \multirow[t]{3}{*}{9} & $\mathrm{~A}$ & 9.6 & $(0.5)$ & 41.2 & $(2.5)$ & 75.4 & $(3.7)$ & $112.0(5.5)$ & 163.0 & $(8.2)$ & 217.3 & (13.1) & $291.6(21.2)$ & $356.7(16.7)$ \\
\hline & B & 9.3 & $(0.5)$ & 37.9 & $(2.7)$ & 73.0 & $(4.5)$ & & & & & & & \\
\hline & $\mathrm{C}$ & 9.6 & $(0.5)$ & 41.5 & $(2.7)$ & 74.7 & $(4.0)$ & & & & & & & \\
\hline \multirow[t]{3}{*}{12} & $\mathrm{~A}$ & 7.9 & $(0.3)$ & 30.8 & (2.9) & 64.0 & $(5.7)$ & & & & & & & \\
\hline & B & 7.5 & $(0.5)$ & 29.8 & (1.8) & 57.9 & (3.9) & & & & & & & \\
\hline & $\mathrm{C}$ & 7.5 & $(0.5)$ & 31.5 & $(1.2)$ & 58.8 & $(1.9)$ & & & & & & & \\
\hline 15 & $\mathrm{~A}$ & 7.1 & $(0.5)$ & 24.3 & (1.6) & 50.6 & (3.3) & $78.7(7.7)$ & 112.0 & $(9.8)$ & 150.6 & $(15.4)$ & $188.4(12.4)$ & $240.5(20.2)$ \\
\hline
\end{tabular}

metamorphosis took from $24 \mathrm{~d}$ at $15^{\circ} \mathrm{C}$ to $117 \mathrm{~d}$ at $3^{\circ} \mathrm{C}$, i.e. from 3.5 wk to almost 4 mo (Table 3 ).

The moult-cycle duration of successive juvenile instars also showed a clear decrease with increasing temperature; e.g. the duration of Crab Stage I varied from $26 \mathrm{~d}$ at $15^{\circ} \mathrm{C}$ to $102 \mathrm{~d}$ at $3^{\circ} \mathrm{C}$. As another consistent trend, the young crab stages showed increasing moultcycle durations in successively later instars. At $15^{\circ} \mathrm{C}$, for example, Crab Stage I lasted on average $26 \mathrm{~d}$, while Crab Stage VI was about twice as long (53 d).

The patterns of development duration ( $y$, days) in relation to temperature $\left(T,{ }^{\circ} \mathrm{C}\right)$ could generally be described with a best fit between observed and predicted data when a power function was used as a model: $y=\mathrm{a} \times T^{\mathrm{b}}$, with a and b being fitted constants; all coefficients of determination, $\mathrm{R}^{2}>0.9$ (Table 4). Only the data for Zoea Stage II fitted better with a logarithmic function: $y=-33.1 \times \log [T]+38.9 ; \mathrm{R}^{2}=0.959$; the power function yielded in this case $\mathrm{R}^{2}=0.929$ ); however, since this was the only exception, herein we consistently use the power function as a general model of developmental temperature-dependence for individual stages as well as for cumulative development times from hatching to successively later stages. The fitted regression parameters and $\mathrm{R}^{2}$ coefficients are compiled in Table 4.

These non-linear patterns are illustrated in Fig. 1a using the untransformed Zoea I data as an example. 
Table 4. Paralomis granulosa. Fitted parameters $(\mathrm{a}, \mathrm{b})$ and coefficients of determination $\left(\mathrm{R}^{2}\right)$ of non-linear regression equations (power functions, $\left.y=\mathrm{a} \times T^{\mathrm{b}}\right)$ describing development time $\left(y\right.$, days) as a function of temperature $\left(T\right.$, $\left.{ }^{\circ} \mathrm{C}\right)$. Dev/stage: time of development in individual stages; Cum. dev: cumulative time of development from hatching to later stages

\begin{tabular}{|lcccccccc|}
\hline Parameter & Zoea I & Zoea II & Megalopa & Crab I & Crab II & Crab III & Crab IV & Crab V \\
\hline Dev/stage & & & & & & & \\
a & 17.8 & 61.3 & 223.4 & 237.4 & 210.0 & 376.6 & 386.4 \\
b & -0.674 & -1.036 & -0.925 & -0.874 & -0.765 & -0.904 & -0.855 \\
$\mathrm{R}^{2}$ & 0.942 & 0.929 & 0.983 & 0.958 & 0.952 & 0.998 & 0.951 \\
Cum. dev & & & & & & & \\
a & & 17.8 & 103.2 & 316.5 & 515.7 & 569.9 & 808.6 & 832.2 \\
b & & -0.674 & -1.048 & -0.950 & -0.874 & -0.734 & -0.730 & -0.626 \\
$\mathrm{R}^{2}$ & & 0.942 & 0.986 & 0.986 & 0.980 & 0.999 & 0.999 & 0.990 \\
\hline
\end{tabular}
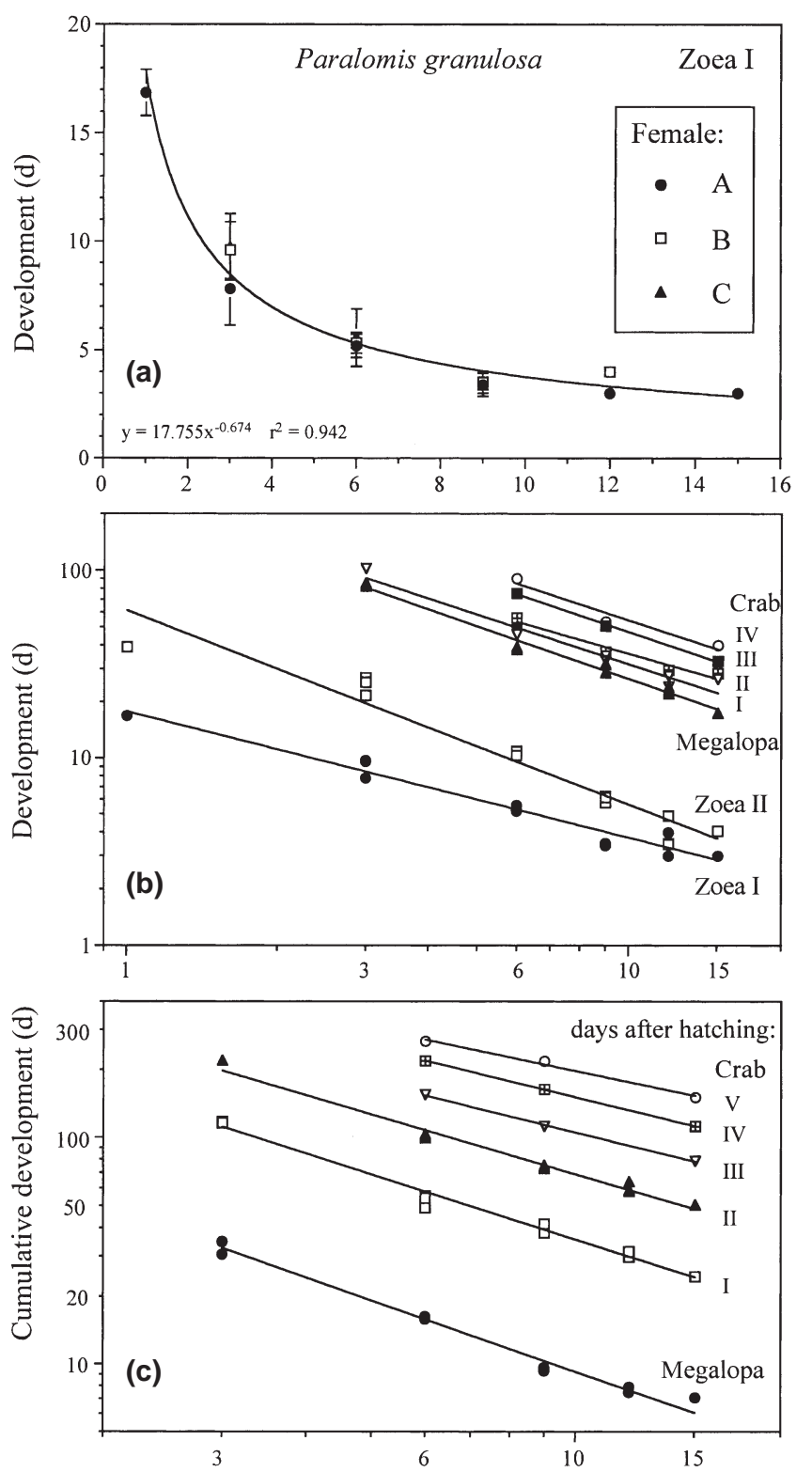

Temperature $\left({ }^{\circ} \mathrm{C}\right)$
The linearized regressions (after log-log transformation) are shown in Fig. 1b for all individual stages for which complete data for a minimum of 3 different temperatures were available (i.e. from Zoea I to the Crab IV; cf. Table 2). The cumulative development duration in relation to temperature is shown in Fig. 1c. The slopes of these regression lines were not significantly different from each other (ANCOVA, $p$ > 0.05), indicating a similar degree of temperature-dependence for successive developmental stages.

\section{DISCUSSION}

Perhaps the most striking result of this study is the wide range of temperatures tolerated by larval and early juvenile stone Paralomis granulosa. At a temperature as low as $1^{\circ} \mathrm{C}$, about one-half of the larvae developed successfully to the megalopa stage, and metamorphosis to the first juvenile crab stage was reached within a tolerance window from 3 to $15^{\circ} \mathrm{C}$. This suggests that the complete mortality before metamorphosis observed in a previous study (Vinuesa et al. 1989) was not caused by unsuitable temperatures but probably was due to either weakness of the larval material or poor rearing conditions.

In the area of origin of our material, the Beagle Channel, the larvae of Paralomis granulosa hatch in winter (July and August: Lovrich \& Vinuesa 1999), when the water temperature is near its average annual minimum $\left(5.4^{\circ} \mathrm{C}\right.$ : Lovrich 1999). Since our experimental data suggest an optimum of about 6 to $9^{\circ} \mathrm{C}$, the larvae and juveniles of this species appear to be optimally

Fig. 1. Paralomis granulosa. Duration of larval and early juvenile development in relation to temperature. (a) Non-linear relationship (power function), Zoea I stage at 1 to $15^{\circ} \mathrm{C}_{\text {; }}$ (b) development of successive stages (Zoea I to Crab IV); (c) cumulative development duration from hatching to successive stages (Megalopa to Crab V) 
adapted to the regional climate near Tierra del Fuego. According to the regional water temperatures in winter and spring, and considering our present results, the larvae should become megalopae 2 to $3 \mathrm{wk}$ after hatching (late July and August), and metamorphosis to the first juvenile crab would be expected to occur throughout September to November. In the following winter, $1 \mathrm{yr}$ after hatching from the egg, the juveniles should approximately reach Crab Instars VI to VII.

At $1{ }^{\circ} \mathrm{C}$ we observed successful development to the Megalopa and larval survival for about 2 mo, suggesting that this species is well adapted to tolerate more severe conditions of cold than those occurring in the Beagle Channel. Theoretically, this capability might enable Paralomis granulosa to occasionally cross the Drake Passage and invade Antarctic waters, although the prevailing current patterns would probably favour an indirect immigration via South Georgia rather than a direct route (see Knox 1994, his Fig. 11.8). With continued global warming, $P$. granulosa may thus be considered a pioneer candidate for a possible recolonization of the Antarctic shelf by reptant decapods. However, earlier invaders may be found among the cold-stenothermal deep-sea lithodids.

The average maximum summer temperature reached in the Beagle Channel is $9.8^{\circ} \mathrm{C}$ (Lovrich 1999). Again, this shows that the tolerated range for larval development in Paralomis granulosa is much wider than would be required within the region of origin of our material. This tolerance of relatively warm conditions (up to at least $15^{\circ} \mathrm{C}$ ) indicates that $P$. granulosa is not really a typical 'cold-adapted', i.e. cold-stenothermal, but actually a cold-eurythermal species (cf. Pörtner et al. 2000, Pörtner 2002). This is consistent with its broad geographic distribution in the subantarctic region and along both sides of southern South America, ranging in the Atlantic north to Santa Catarina, Brazil (Boschi et al. 1992), and in the Pacific to the Island of Chiloé, Chile (Retamal 1981). Likewise, this response pattern is congruent with the observation that $P$. granulosa is the only species of its genus that also inhabits shallow coastal waters where temperatures may be quite variable (Macpherson 1988).

The thermal response pattern of the early life-history stages of Paralomis granulosa may be typical of those Lithodidae (or at least of Paralomis and Lithodes spp.) that live in high latitudes, commonly with wide ranges of geographic and bathymetric distribution (for references see Paul et al. 2002). In contrast, true deep-sea species living in a more stable environment should be cold-stenothermal. Since our observations show that the larvae and juveniles of $P$. granulosa are coldeurythermal, they should be an interesting object for testing the physiological hypotheses of thermal tolerance recently proposed by Pörtner $(2001,2002)$. These hypotheses suggest that this species, including its early life-history stages, should be capable of regulating its mitochondrial densities and/or its energetic capacity in response to seasonal, bathymetric, or regional changes in temperature, or after differential acclimatization in the laboratory.

With regard to extremely long periods of larval development at low temperature $\left(<6^{\circ} \mathrm{C}\right)$, it should be stressed that during this time no intake of food occurs, and development depends solely on the utilization of internal energy reserves. Although an extended lecithotrophic period under cold conditions indicates low rates of metabolic consumption, successful nonfeeding development over a period of up to $4 \mathrm{mo}$ remains highly remarkable, since metabolic disturbance below a critical temperature leads to insufficient cellular oxygen and energy supplies (Pörtner 2001, 2002), which may eventually prevent effective utilization of internal energy reserves. When larvae of warmtemperate crab species were simultaneously exposed to unfavourably low temperatures and an absence of food, they died sooner than sibling larvae starving at higher temperatures, although metabolic energy demands increase at higher temperatures, and thus one would expect shorter survival times in warmer waters (Anger et al. 1981).

In summary, our study has shown that Paralomis granulosa is well adapted to thrive under the conditions of food limitation and cold found in high-latitude marine ecosystems. On the other hand, it is equally well adapted to cool temperate regions, where relatively elevated temperature levels exclude truly coldadapted stenothermal species. Thus, a remarkable larval eurythermal ability together with an unusually high endotrophic potential allow extended periods of completely food-independent development from hatching through metamorphosis in this species.

Similar patterns were also observed in a stone crab from the North Atlantic, Lithodes maja (Anger 1996), as well as in a Pacific congener, L. aequispinus (Shirley \& Zhou 1997). In the latter species, the maximum period of non-feeding larval development (148 d at $3^{\circ} \mathrm{C}$ : Paul \& Paul 1999) even exceeds, by $1 \mathrm{mo}$, the maximum time observed in Paralomis granulosa. Successful larval development at $9^{\circ} \mathrm{C}$ as well as a wide geographic distribution (from Japan to the Bering Sea, Canada and Alaska: Zaklan 2002) suggest that, like $P$. granulosa, $L$. aequispinus is a eurythermal rather than a cold-stenothermal species.

The occurrence of ovigerous females of Lithodes maja in coastal waters of Greenland, where water temperatures between -1 and $5^{\circ} \mathrm{C}$ were recorded (Woll \& Burmeister 2002) suggests cold resistance in the early life-history stages of this species similar to that in Paralomis granulosa and (probably) L. aequispinus. Al- 
though no data on temperature effects are available for larvae of $L$. maja, a longer development from hatching to metamorphosis (about $50 \mathrm{~d}$ at $9^{\circ} \mathrm{C}$ : Anger 1996) than in P. granulosa (38 to $42 \mathrm{~d}$ ) suggests that $L$. maja also passes through a very long non-feeding larval development at low temperatures. In this species also, the early life-history stages are not cold-stenothermal but eurythermal, as reflected by its wide geographic distribution from the southern North Sea to Spitzbergen, Iceland and Greenland (Zaklan 2002).

These patterns contrast with those of the commercially more important lithodid Paralithodes camtschatica. Although this species also occurs at high latitudes (Stevens 2002, Sundet \& Hjelset 2002) and its larvae tolerate a wide range of temperatures, from low to moderately high $\left(0\right.$ to $15^{\circ} \mathrm{C}$ : Shirley \& Shirley 1989$)$, its zoeae are known to require planktonic food (e.g. Kurata 1960, Paul \& Paul 1980); however, its megalopa stage is secondarily lecithotrophic (see Abrunhosa \& Kittaka 1997a,b).

While these comparisons of larval tolerance of cold and food limitation show that not all lithodid crabs occurring at high latitudes have reached the same degree of adaptation to thermally and nutritionally harsh conditions, similarities among the various species suggest that a combination of larval eurythermality and lecithotrophy may be a widespread trait in lithodids. Phylogenetic constraints in other reptant Decapoda may not generally allow for an evolution of such special adaptations and may thus have contributed to both gradients of decreasing species diversity and to the tendency towards a reduction of the larval phase with increasing latitude ('Thorson's rule').

Acknowledgements. We greatly appreciate the help of the crew of PFS 'Polarstern' during the transport of live crabs. U. Nettelmann and several students helped in maintaining larval and juvenile cultures. J.C. is grateful to the German Academic Exchange Service (DAAD, Bonn) and the AlfredWegener-Institut für Polar- und Meeresforschung (Bremerhaven) for funding his research visits to Helgoland. This project was funded by the International Bureau of the German Ministry of Scientific Research (BMBF, project no. ARG 99/002), and the Argentine Secretaría Nacional para la Tecnología, Ciencia e Inovación Productiva (SETCIP).

\section{LITERATURE CITED}

Abrunhosa FA, Kittaka J (1997a) Morphological changes in the midgut, midgut gland and hindgut during the larval and postlarval development of the red king crab Paralithodes camtschaticus. Fish Sci 63:746-754

Abrunhosa FA, Kittaka J (1997b) Functional morphology of mouthparts and foregut of the last zoea, glaucothoe and first juvenile of the king crabs Paralithodes camtschaticus, $P$. brevipes and $P$. platypus. Fish Sci 63:923-930

Anger K (1996) Physiological and biochemical changes during lecithotrophic larval development and early juvenile growth in the northern stone crab, Lithodes maja (Decapoda: Anomura). Mar Biol 126:283-296

Anger K (2001) The biology of decapod crustacean larvae. Crustacean issues, 14. AA Balkema, Lisse

Anger K, Dawirs RR, Anger V, Goy JW, Costlow JD (1981) Starvation resistence in first stage zoeae of brachyuran crabs in relation to temperature. J Crustac Biol 1:518-525

Arana PME, Retamal MA (1999) Nueva distribución de Paralomis birstein Macpherson, 1998 en aguas Antárticas (Anomura, Lithodidae, Lithodinae). Investig Mar Univ Catol Valpso 27:101-110

Arntz WE, Gorny M (1991) Shrimp (Decapoda, Natantia) occurrence and distribution in the eastern Weddell Sea, Antarctica. Polar Biol 11:169-177

Arntz WE, Brey T, Gallardo VA (1994) Antarctic zoobenthos. Oceanogr Mar Biol Annu Rev 32:241-304

Arntz WE, Gutt J, Klages M (1997) Antarctic marine biodiversity: an overview. In: Battaglia B, Valencia J, Walton DWH (eds) Antarctic communities: species, structure and survival. Cambridge University Press, Cambridge, p 3-14

Arntz WE, Gorny M, Soto R, Lardies MA, Retamal MA, Wehrtmann IS (1999) Species composition and distribution of decapod crustaceans in the waters off Patagonia and Tierra del Fuego, South America. Sci Mar 63(Suppl 1): 303-314

Boschi EE, Fischbach CE, Iorio MI (1992) Catálago ilustrado de los crustáceos estomatópodos y decápodos marinos de Argentina. Frente Marit, Urug 10:7-94

Calcagno JA, Anger K, Lovrich GA, Thatje S, Kaffenberger A (in press) Larval development of the subantarctic king crabs Lithodes santolla and Paralomis granulosa reared in the laboratory. Helgol Mar Res

Campodonico GI, Guzman L (1981) Larval development of Paralomis granulosa (Jacquinot) under laboratory conditions (Decapoda, Anomura, Lithodidae). Crustaceana 40: 272-285

Chevaldonné P, Olu K (1996) Occurrence of anomuran crabs (Crustacea: Decapoda) in hydrothermal vent and cold-seep communities: a review. Proc Biol Soc Wash 109:286-298

Chown SL, Gaston KJ, Gremmen NJM (2000) Including the Antarctic: insights for ecologists everywhere-Antarctic ecosystems: models for wider ecological understanding. NZ Nat Sci 2000:1-16

Christiansen ME, Christiansen BO (1962) The Crustacea Decapoda of Isfjorden: a comparison with the Swedish Spitsbergen expedition in 1908. Acta Borealia A Sci 19:1-52

Clarke A (1993) Temperature and extinction in the sea: a physiologist's view. Paleobiology 19:499-518

Clarke A (1997) The influence of climate change on the distribution and evolution of organisms. In: Johnston IA, Bennett AF (eds) Animals and temperature: phenotypic and evolutionary adaptations. Cambridge University Press, Cambridge, p 377-407

Crame JA (1999) An evolutionary perspective on marine faunal connections between southernmost South America and Antarctica. Sci Mar 63(Suppl 1):1-14

Crame JA, Clarke A (1997) The historical component of marine taxonomic gradients. In: Ormond RFG, Gage JD, Angel MV (eds) Marine biodiversity. Cambridge University Press, Cambridge, p 258-273

Dawson EW (1989) King crabs of the world (Crustacea: Lithodidae) and their fisheries: a comprehensive bibliography. Misc Publ NZ Oceanogr Inst 101:1-338

Frederich M, Sartoris FJ, Arntz WE, Pörtner HO (2000) Haemolymph $\mathrm{Mg}^{2+}$ regulation in decapod crustaceans: physiological correlates and ecological consequences in polar areas. J Exp Ecol 203:1383-1393 
Frederich M, Sartoris FJ, Pörtner HO (2001) Distribution patterns of decapod crustaceans in polar areas: a result of magnesium regulation? Polar Biol 24:719-723

Gallardo CS, Penchaszadeh PE (2001) Hatching mode and latitude in marine gastropods: revisiting Thorson's paradigm in the southern hemisphere. Mar Biol 138:547-552

Gore RH (1985) Molting and growth in decapod larvae. In: Wenner AM (ed) Larval growth. Balkema, Rotterdam, p 1-65

Gorny M (1999) On the biogeography and ecology of the Southern Ocean decapod fauna. Sci Mar 63(Suppl 1): 367-382

Kattner G, Graeve M, Calcagno J, Lovrich G, Thatje S, Anger $\mathrm{K}$ (in press) Lipid, fatty acid and protein utilisation during lecithotrophic larval development of Lithodes santolla (Molina) and Paralomis granulosa (Jacquinot). J Exp Mar Biol Ecol

Klages M, Gutt J, Starmans A, Bruns T (1995) Stone crabs close to the Antarctic continent: Lithodes murrayi Henderson, 1888 (Crustacea; Decapoda; Anomura) off Peter I Islands $\left(68^{\circ} 51^{\prime} \mathrm{S}, 90^{\circ} 51^{\prime} \mathrm{W}\right)$. Polar Biol 15:73-75

Knox GA (1994) The biology of the Southern Ocean. Cambridge University Press, Cambridge

Kurata H (1960) Studies on the larva and post-larva of Paralithodes camtschatica. III. The influence of temperature and salinity on the survival and growth of the larva. Bull Hokkaido Reg Fish Res Lab 21:9-14

Lovrich GA (1997) La pesquería mixta de las centollas Lithodes santolla y Paralomis granulosa (Anomura: Lithodidae) en Tierra del Fuego, Argentina. Investig Mar Univ Catol Valpso 25:41-57

Lovrich GA (1999) Seasonality of larvae of Brachyura and Anomura (Crustacea Decapoda) in the Beagle Channel, Argentina. Sci Mar 63(Suppl 1):347-354

Lovrich GA, Vinuesa JH (1999) Reproductive potential of the lithodids Lithodes santolla and Paralomis granulosa (Anomura, Decapoda) in the Beagle Channel, Argentina. Sci Mar 63(Suppl 1):355-360

Lovrich GA, Thatje S, Calcagno JA, Anger K, Kaffenberger A (2003) Changes in biomass and chemical composition during lecithotrophic larval development of the southern king crab, Lithodes santolla (Molina). J Exp Mar Biol Ecol 288:65-79

Macpherson E (1988) Revision of the family Lithodidae Samouelle, 1819 (Crustacea, Decapoda, Anomura) in the Atlantic Ocean. Monogr Zool Mar 2:9-153

McLaughlin PA, Anger K, Kaffenberger A, Lovrich GA (2001) Megalopal and early juvenile development in Lithodes santolla (Molina, 1782) (Decapoda: Anomura; Paguroidea: Lithodidae), with notes on zoeal variations. Invertebr Reprod Dev 40:53-67

McLaughlin PA, Anger K, Kaffenberger A, Lovrich GA (in press) Larval and early juvenile development in Paralomis granulosa (Jacquinot) (Decapoda: Anomura: Paguroidea: Lithodidae), with emphasis on abdominal changes in megalopal and crab stages. J Nat Hist

Paul AJ, Paul JM (1980) The effect of early starvation on later feeding success of king crab zoeae. J Exp Mar Biol Ecol 44: $247-251$

Paul AJ, Paul JM (1999) Development of larvae of the golden king crab Lithodes aequispinus (Anomura: Lithodidae) reared at different temperatures. J Crustac Biol 19: $42-45$

Paul AJ, Dawe EG, Elner R, Kruse GH, Otto RS, Sainte-Marie B, Shirley T, Woodby D (2002) Crabs in cold waters: biology, management, and economics. Alaska Sea Grant Publications, Anchorage, AK
Pörtner HO (2001) Climatic change and temperature dependent biogeography: oxygen limitation of thermal tolerance in animals. Naturwissenschaften 88:137-146

Pörtner HO (2002) Climate variations and the physiological basis of temperature dependent biogeography: systemic to molecular hierarchy of thermal tolerance in animals. Comp Biochem Physiol A 132:739-761

Pörtner HO, Van Dijk PLM, Hardewig I, Sommer A (2000) Levels of metabolic cold adaption: tradeoffs in eurythermal and stenothermal ectotherms - Antarctic ecosystems: models for wider ecological understanding. New Zealand Natural Sciences 2000:109-122

Rabalais NN, Gore RH (1985) Abbreviated development in decapods. In: Wenner AM (ed) Larval growth. Balkema, Rotterdam, p 67-126

Retamal MA (1981) Catalogo ilustrado de los crustaceos decapodos de Chile. Gayana Zool 44:1-110

Rex MA, Etter RJSCT (1997) Large-scale patterns of species diversity in the deep-sea benthos. In: Ormond RFG, Gage JD, Angel MV (eds) Marine biodiversity. Cambridge University Press, Cambridge, p 94-121

Shirley TC, Shirley SM (1989) Temperature and salinity tolerances and preferences of red king crab larvae. Mar Behav Physiol 16:19-30

Shirley TC, Zhou S (1997) Lecithotrophic development of the golden king crab Lithodes aequispinus (Anomura: Lithodidae). J Crustac Biol 17:207-216

Sokal RR, Rohlf FJ (1995) Biometry: the principles and practice of statistics in biological research, 3rd edn. WH Freeman, New York

Spivak ED (1997) Los crustáceos decápodos del Atlántico sudoccidental $\left(25^{\circ}-55^{\circ} \mathrm{S}\right)$ : distribución y ciclos de vida. Investig Mar Univ Catol Valpso 25:69-91

Stevens BG (2002) Checklist of Alaskan crabs. In: Paul AJ, Dawe EG, Elner R, Jamieson GS and 5 others (eds) Crabs in cold water regions: biology, management, and economics. University of Alaska Sea Grant College Program AKSG-02-01, University of Alaska, Fairbanks, p 5-8

Stilwell JD, Feldmann RM (2000) Paleobiology and paleoenvironments of Eocene rocks, McMurdo Sound, East Antarctica. Antarct Res Ser 76:1-372

Sundet JH, Hjelset AM (2002) The Norwegian red king crab (Paralithodes camtschaticus) fishery: management and bycatch issues. In: Paul AJ, Dawe EG, Elner R, Jamieson GS and 5 others (eds) Crabs in cold water regions: biology, management, and economics. University of Alaska Sea Grant College Program AK-SG-02-01, University of Alaska, Fairbanks, p 681-692

Thorson G (1950) Reproductive and larval ecology of marine bottom invertebrates. Biol Rev 25:1-45

Vinuesa JH, Lovrich GA, Comoglio LI (1989) Temperaturesalinity effects on the larval development in false southern king crab, Paralomis granulosa (Crustacea, Anomura). Thalassas (Revta Cienc Mar Santiago de Copostela) 7:53-57

Woll AK, Burmeister A (2002) Occurance of northern stone crab (Lithodes maja) at southeast Greenland. In: Paul AJ, Dawe EG, Elner R, Jamieson GS and 5 others (eds) Crabs in cold water regions: biology, management, and economics. University of Alaska Sea Grant College Program AK-SG-02-01, University of Alaska, Fairbanks, p 733-749

Zaklan SD (2002) Review of the family Lithodidae (Crustacea: Anomura: Paguroidea): distribution, biology, and fisheries. In: Paul AJ, Dawe EG, Elner R, Jamieson GS and 5 others (eds) Crabs in cold water regions: biology, management, and economics. University of Alaska Sea Grant College Program AK-SG-02-01, University of Alaska, Fairbanks, p 751-845 